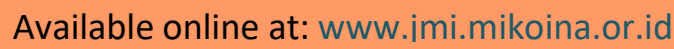 Jurnal Mikologi Indonesia

\section{Sphaerobolus stellatus: Cannonball Mushroom from West Java}

\section{Rudy Hermawan ${ }^{1}$, Indra Maulana ${ }^{1}$}

${ }^{1}$ Department of Biology, Faculty of Mathematics and Natural Sciences, IPB University, Dramaga Campus, Bogor 16680, Indonesia

Hermawan R, Maulana I. 2020 - Sphaerobolus stellatus: Cannonball Mushroom from West Java. Jurnal Mikologi Indonesia 4(2), 218-222. doi:10.46638/jmi.v4i2.86

\begin{abstract}
Cannonball mushroom is known as the unique genera in Basidiomycetes. This micromushroom is the first recorded in Indonesia. The specimen was deposited into Herbarium Bogoriense with code BO 24422. The Sphaerobolus was found on the rotten wood in Landscape Arboretum of IPB University. The fruiting body has similar morphology between Geastrum and Pilobolus. The mushroom has an exoperidium (like Geastrum outer) and endoperidium (like Pilobolus head). The basidiospore is hyaline, globose to elongate, and having circular gradation on the surface. Sphaerobolus is known as lignicolous, phototrophic, and sometimes as coprophilous fungus. Sphaerobolus was classified into Geastrales and Sphaerobolaceae. BO 24422 specimen is classified as S. stellatus.
\end{abstract}

Keywords - Herbarium Bogoriense - lignicolous - phototropic fungi - unusual-shaped mushroom

\section{Introduction}

Cannonball mushroom is known as a unique micro-mushroom because of the unusual shape of the fruiting body. This micro-mushroom commons with the name "Artillery Fungus" (Walker, 1927; Brantley et al., 2001 ${ }^{\mathrm{a}}$ ). The genus of this cannonball or artillery fungus is Sphaerobolus (Leonard \& Volk, 2005). Sphaerobolus was built by Tode in 1790 and previously known as the other name, Carpobolus by Micheli (1729). The shape looks like Geastrum with exoperidium and endoperidium. This peridium (endoperidium) is capable of ejecting toward its environment (Buller, 1933). Despite Sphaerobolus is a unique mushroom, it is not really popular. The current study of this genus is limited.

Geml et al. $\left(2005^{\mathrm{a}}\right)$ studied about the systematics of Sphaerobolus. The phylogram showed three species i.e. S. ingoldii, S. iowensis, and S. stellatus with good clades separated from each species. In a previous study, the genus contains two species, S. stellatus (Tode) Pers. and S. iowensis Walker (Hawksworth et al., 1996). Then, Gem et al. $\left(2005^{\mathrm{b}}\right)$ found one specimen in Sphaerobolus called undescribed Sphaerobolus. The continued study by Geml et al. $\left(2005^{\mathrm{a}}\right)$ built the specimen as a new species in Sphaerobolus, namely $S$. ingoldii. The morphology of this genus must show the specific character of Gastromycetes fungi. The other genera such as Cyathus, Geastrum, Lycoperdon, and Lysurus are same as the member (Hosaka et al., 2006). Literally, Ulloa \& Hanlin (2000) classified Sphaerobolus into Nidulariales. Nevertheless, the current study from Hosaka et al. (2006) classified Sphaerobolus into Geastrales.

The distribution of Sphaerobolus is more often reported in America and the Netherlands (Geml et al., 2005ª). In Asia, Sphaerobolus stellatus was found and reported in

Dikirimkan 8 Agustus 2020, Diterima 26 November 2020, Terbit online 15 Desember 2020

Corresponding Author: Rudy Hermawan, e-mail: hermawan_rudy@apps.ipb.ac.id 
the Philippines (Global Fungal Red List Initiative, 2015). While, in Indonesia is not reported yet for the distribution. This fungus is known as artillery fungus, and sometimes also known as a lignicolous and as a coprophilous fungus (Geml et al., 2005 ${ }^{\mathrm{b}}$ ). Moreover, the Sphaerobolus had been reported as a pest (McRitchie, 1995) and black spot on the house woody furniture (Lehman, 1985).

\section{Materials and Methods \\ Site and Time of Sampling and Experiment}

The sampling of the cannonball mushroom was conducted on 5 January 2020 and was located in Landscape Arboretum of IPB University, West Java, Indonesia. The sampling site was specifically around the litter, debris, or rotten wood. The characterization of fruiting body was conducted in the mycology laboratory, Biology Department, Mathematics and Natural Science Faculty, IPB University.

\section{Morphological Observation}

Mushrooms were documented on the spot and collected, then observed the fresh fruiting body. The important characters of fruiting body such as shape, size, ornamentation, and spores were observed and documented. The fruiting body was preserved in FAA (Kottapalli et al., 2016) and deposited in Herbarium Bogoriense, LIPI, Indonesia.

\section{Results}

\section{Specimens}

Cannonball mushroom was found in Landscape Arboretum only on rotten wood (Figure 1a). It was found gregarious on the spot, occasionally solitary. The fruiting body was found for two types. The first type is a fruiting body that out of endoperidium, and the other is completed with endoperidium (Figure 1b-d). The fruiting bodies were attached to the rotten wood without the stem. The morphology only like exoperidium and endoperidium. The specimen was deposited into Herbarium Bogoriense, LIPI, Indonesia, with the code BO 24422. It was collected by Rudy Hermawan and Indra Maulana on 5 January 2020.

\section{Description}

The mature fruiting body has two parts, i.e. exoperidium and endoperidium. It resembles with Geastrum morphology, but different on endoperidium. The endoperidium is light orange with globose to ellipsoid (Figure 1b-d) shape and 15-19 $\times 8-11 \mathrm{~mm}$. The endoperidium will explode when the light is enough for energy (Figure 1e). The young stage of Sphaerobolus looks like the egg covered by whitish mycelia (Figure 1f2). Then, the next development is that herein with the exoperidium is opened and shows the young endoperidium (Figure 1f1). The endoperidium contains basidiospores. Basidiospores are ellipsoid and sometimes globose (Figure 1g); free ornament; appeared of gradation line circular inside; hyaline; and 7.0-8.7 × 4.0-5.2 $\mu \mathrm{m}$.

\section{Discussion}

The unusual-shaped mushrooms are rarely to be explored in Indonesia. Hermawan et al. (2020) had reported some of the unusual mushrooms which were found on the harsh land in South Kalimantan, such as Ramaria and Lycoperdon. Other unusual-shaped mushrooms also come from the micro-mushroom group. Sphaerobolus is one of the unique and unusualshaped micro-mushrooms. The fruiting body has a similarity between Geastrum and Pilobolus. The similarity of Geastrum is in the exoperidium part. In contrast, the morphology of peridiole (endoperidium or sometimes called gleba) is same as the head of Pilobolus. Although Sphaerobolus has a similar part to Pilobolus, the order of Sphaerobolus is classified 
into Geastrales. Hosaka et al. (2006) confirmed and classified the Sphaerobolus into the Geastrales.

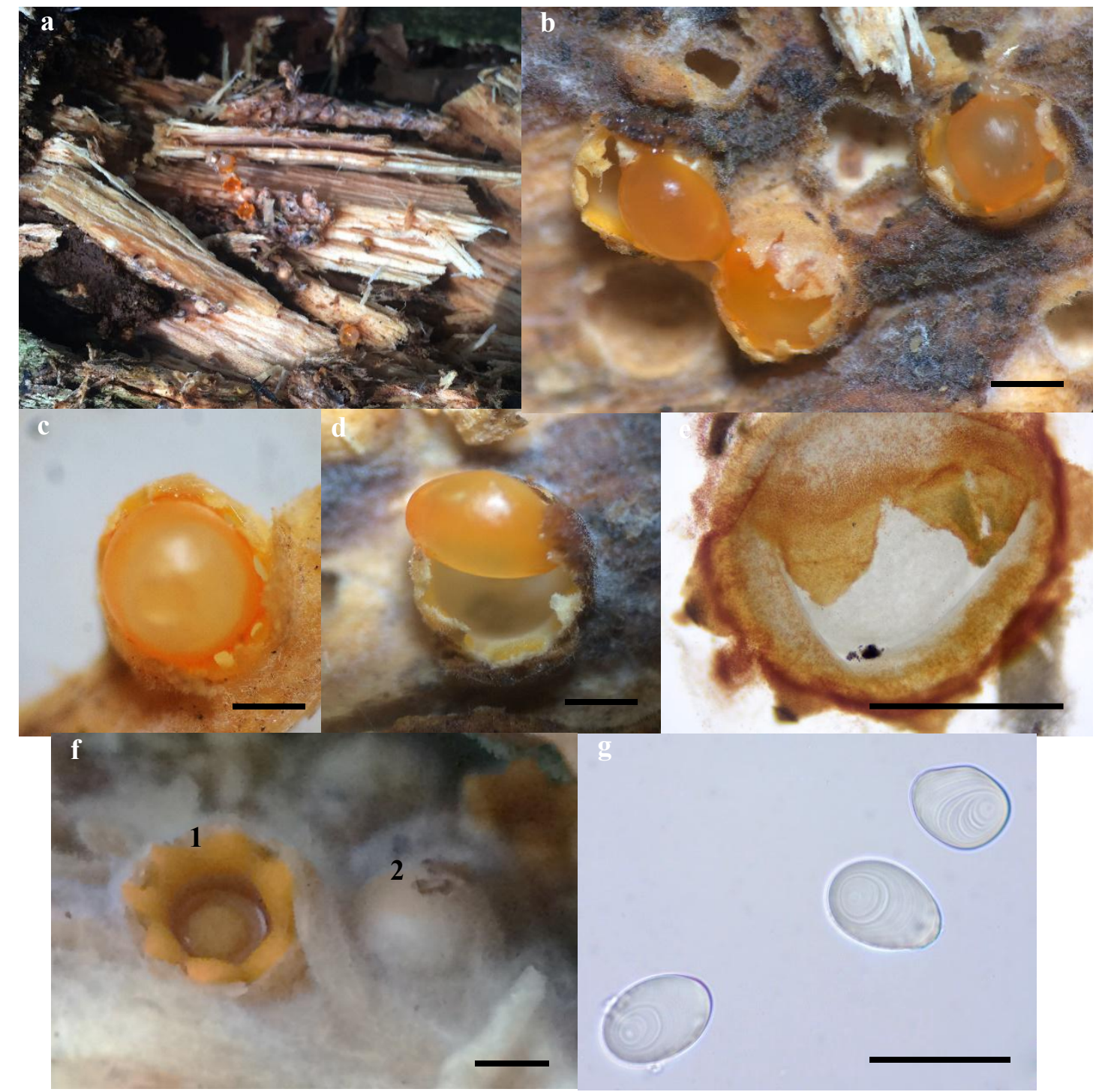

Figure 1. Sphaerobolus stellatus. (a) Sphaerobolus on rotten wood; (b-d) fruiting body of Sphaerobolus; (e) peridiole or endoperidium broken; (f) endoperidium appeared (1), immature fruiting body (2); (g) basidiospores. Scale bars: $1 \mathrm{~cm}(\mathrm{~b}-\mathrm{f})$; and $10 \mu \mathrm{m}(\mathrm{g})$.

The morphological characters are really supported when the shape of Sphaerobolus has globose-shaped when the young stage and looks like an egg phase in Geastrum. Hosaka et al. (2006) showed the relationship between Sphaerobolus and Geastrum is really closer based on the phylogenetic using multigene analyses in Bayesian analyses, i.e. LR0R-LR3 region for nuclear large subunit ribosomal DNA (nucLSU-rDNA); MS1-MS2 region for mitochondrial small subunit ribosomal DNA (mt-SSU-rDNA); ATPase subunit 6 (atp6); bRPB2-6F-bRPB2-7R region for the second largest subunit of RNA polymerase (RPB2); and EF1-983F-EF1-1567R region for translation elongation factor subunit 1a (EF-1a).

The young stage (Figure 1f2) of Sphaerobolus looks like an egg wrapped by white cottony hyphae. According to Birchfield et al. (1957), the egg or tiny sphere will develop inside the wrapped hyphae. The egg attains to $0.2 \mathrm{~cm}$. This shape is the immature phase of Sphaerobolus. Some fruiting bodies develop with the mucilage inside the developed egg. This mucilage has been mentioned by Ingold (1971) who observed the development of the 
Sphaerobolus peridiole (endoperidium). In the previous report, Sphaerobolus is classified into Nidulariaceae, same as Cyathus. Because of the naming of peridiole, the Sphaerobolus is usually considered as a "flying" spore packet, exactly like the spore dispersal system in Cyathus. Some previous reports also had called Sphaerobolus as phototropic fungi, such as Dasyobolus, Pilobolus, and Podospora (Ingold, 1972). Ingold observed the parallel adaptation for phototropic response between Dasyobolus, Pilobolus, Podospora, and Sphaerobolus. Among those fungi, Sphaerobolus is the range shooter that can shoot the basidiospores to the environment.

The fruiting body has yellow with a cannonball shaped-like. Sometimes the exoperidium has 6-8 triangular of the outer skin and peel erected. Sphaerobolus has six layers when the egg phase (immature phase) (Ingold, 1972). When becoming a mature fruiting body, it will have a thin layer in endoperidium (peridiole). According to figure 1e, there is liquid inside the peridium which bears the basidiospores. Naturally, the thin layer will be broken by the light energy absorption. Based on Ingold (1972), Sphaerobolus can discharge the basidiospores until $200 \mathrm{~cm}$ of length from the fruiting body. The basidiospore of Sphaerobolus is elongated to globose. There is a pattern on the surface that seems like circular gradation. This type is unique among other genera of micro-mushroom. Based on the morphological characters, the BO 24422 specimen is Sphaerobolus stellatus. Geml et al. $\left(2005^{b}\right)$ mentioned the different sizes and characters among three species in Sphaerobolus.

The spore discharged is usually helped by insects like ants. According to our field exploration, some ants touch and break the endoperidium naturally. They distribute the spores when the ants walk and move to many areas on rotten wood. These micro-mushrooms have a cosmopolitan distribution (Geml et al., 2005 ) and are usually decaying wood (Lehman, 1985). Therefore, Sphaerobolus can be called as white rotting fungi. The potency of Sphaerobolus is not reported yet. Nevertheless, Sphaerobolus was reported that be a pest to the foliage industry (McRitchie, 1995). On the other hand, Brantley et al. (2001 ${ }^{\text {a }}$ ) had studied about controlling Sphaerobolus stealus using mulch products to avoid their sporulation. But there was no mulch that can control their sporulation. Then, Brantley et al. (2001 ${ }^{\mathrm{b}}$ ) reported controlling of Sphaerobolus. The study resulted in the isolates of Trichoderma harzianum and Bacillus subtilis can control the S. stellatus growth in vitro.

\section{References}

Birchfield, W., Smith. J. L., Martinez, A., \& Matherly, E. P. (1957). Chinese evergreen plants rejected because of glebal masses of Sphaerobolus stellatus on foliage. Plant Disease Reporter, 41, 537-539.

Brantley, E. A., Davis, D. D. \& Kuhns, L. J. (2001 $\left.{ }^{\mathrm{a}}\right)$. Influence of mulch characteristics on the sporulation of the artillery fungus Sphaerobolus stellatus. J Environ Hort, 19, 89-95. https://doi.org/10.24266/0738-2898-19.2.89

Brantley, E. A., Davis, D. D. \& Kuhns, L. J. $\left(2001^{\mathrm{b}}\right)$. Biological control of the artillery fungus, Sphaerobolus stellatus, with Trichoderma harzianum and Bacillus subtilis. $J$ Environ Hort, 19, 21-23. https://doi.org/10.24266/0738-2898-19.1.21

Buller, A. H. R. (1933). Researches on fungi. Vol. 5. London: Longmans, Green \& Co.

Geml, J., Davis, D. D. \& Geiser, D. M. (2005ª). Phylogenetic analyses reveal deeply divergent species lineages in the genus Sphaerobolus (Phallales: Basidiomycota). Mol Phyl Evol, 35, 313-322. https://doi.org/10.1016/j.ympev.2005.01.014

Geml, J., Davis, D. D. \& Geiser, D. M. $\left(2005^{\mathrm{b}}\right)$. Systematics of the genus Sphaerobolus based on molecular and morphological data, with the description of Sphaerobolus ingoldii sp. nov. Mycologia, 97, 680-694. https://doi.org/10.1080/15572536.2006.11832798

Hawksworth, D. L., Kirk, P. M., Sutton, B. C. \& Pegler, D. N. (1996). Ainsworth \& Bisby's Dictionary of the Fungi. 8th ed. Oxford University Press Inc, New York. 
Hermawan R., Imaningsih, W., \& Badruzsaufari. (2020). Mushrooms assumed as ectomycorrhizal fungi on South Kalimantan serpentine soil. J Mikologi Indonesia, 4, 149-155. https://doi.org/10.46638/jmi.v4i1.71

Hosaka, K., Bates, S. T., Beever, R. E., Castellano, M. A., Colgan, I. I. I. W., Dominguez, L. S., Nouhra, E. R., Geml, J. \& Trappe, J. M. (2006). Molecular phylogenetics of the Gomphoid-Phalloid Fungi with an establishment of the new subclass Phallomycetidae and two new orders. Mycologia, 98, 949-959. https://doi.org/10.3852/mycologia.98.6.949

Ingold, C. T. (1971). The glebal mass of Sphaerobolus. Trans Br Mycol Soc, 56, 105-113. https://doi.org/10.1016/S0007-1536(71)80114-6

Ingold, C. T. (1972). Sphaerobolus: the story of a fungus. Trans Br Mycol Soc, 58, 179-195. https://doi.org/10.1016/S0007-1536(72)80147-5

Kottapalli, S., Krishna, H., Venumadhav, K., Nanibabu, B., Jamir, K., Ratnamma, B. K., Jena, R. \& Babarao, D. K. (2016). Preparation of herbarium specimen for plant identification and voucher number. Roxburghia, 6, 111-119.

Lehman, R. D. (1985). Black spots on houses -- An insect or disease problem? Pennsylvania Department of Agriculture Bureau of Plant Industry, Reg Hort, 11, 15-16.

Leonard, L. \& Volk, T. J. (2005). Tom Volk's Fungus of the Month for July 2005, Sphaerobolus stellatus, the cannonball fungus. www.botit.botany.wisc.edu/toms_fungi/jul2005.html (accessed 16 June 2020).

McRitchie, J. J. (1995). Sphaerobolus stellatus on foliage ornamentals. Plant Pathol Cir, 371, $1-2$.

Micheli, P. A. (1729). Nova Plantarum Genera. Florence, Italy.

The Global Fungal Red List Initiative. (2015). Sphaerobolus stellatus. http://iucn.ekoo.se/iucn-/species_view/196509/ (accessed 6 June 2020).

Ulloa, M. \& Hanlin, R. T. (2000). Illustrated Dictionary of Mycology. APS Press, St Paul Minnesota.

Walker, L. B. (1927). Development and mechanism of discharge in Sphaerobolus iowensis n. sp. and S. stellatus Tode. J. Elisha Mitchell Sci Soc, 12, 151-178. 